\title{
The regulation of pregnancy in Mozambican schools: from policy, to practice, to identities
}

\section{Francesca Salvi}

\begin{abstract}
This article discusses how institutional practices reproduce and operationalize specific discourses of in-school pregnancy and motherhood in Mozambique. National Decree 39/GM/2003 indicates that girls should be transferred to night courses if pregnant, together with their partners, if also students. This paper considers the implementation of this policy by identifying key roles such as those of Physical Education teachers, in-school pregnancy committees and class representatives. Drawing on qualitative data from 12 focus groups and 63 individual interviews with adults and young people, I claim that school practices mostly rely on acts of policing the female body. The result is the reproduction of a specific institutional regime that defines pupils' identities along gender and age, by means of their (hetero)sexuality and seniority. Subsequently, the national policy, which was introduced to retain girls within education, figures as exclusionary, as students who do not meet the identity regime identified above are excluded from education.
\end{abstract}

\section{Keywords}

Mozambique, teenage pregnancy, schooling, gender, policy.

\section{Funding}

This work was supported by the Economic and Social Research Council [grant number ES/I900934/1]. 


\section{Introduction}

Academic research and policy-makers generally construct teenage pregnancy as problematic. For instance, a recent United Nations Population Fund (UNFPA) report indicates (2013, ii):

When a girl becomes pregnant, her present and future change radically, and rarely for the better. Her education may end, her job prospects evaporate, and her vulnerabilities to poverty, exclusion and dependency multiply.

This doom-laden definition simplistically associates in-school pregnancy with the interruption of education and training. Education is represented as a means to personal development and success, through the acquisition of skills leading to formal employment and individual empowerment. Although relevant on a global scale, this point is particularly salient in relation to disadvantage and in the context of development, where teenage pregnancy is often associated with gender inequalities. The instrumentalization of education explicitly points to the persistence of Women In Development (WID) approaches. These are dominated by human capital theories, which fail to understand the role played by contexts and structures in understanding individual behaviors. In this sense, schooling is constructed as a symbol of - or entrance to - modernity, while pregnancy and parenthood are defined in terms of the opportunities they prevent. From this perspective, in-school pregnancy works against individual and social progress and is synonymous with backwardness and tradition within a modernizing and globalized world.

Yet, childbearing and motherhood have been the 'main source of a woman's respect' since the precolonial period across most of the African continent (Iliffe 2005, 264). In Mozambique, this invokes a regulatory framework which puts pressure on girls to have children early (Loforte 2007, 29). Indeed, young women contribute significantly to the 
country's fertility rate. According to the latest three Demographic Health Surveys (1997, 2003 and 2011), the percentage of teenagers (15-19) who have begun childbearing remains somewhat stable at 40\%. Yet, the more recent AIDS Indicators Survey (AIS) 2015 (Ministério da Saúde (MISAU), Instituto Nacional de Estatística (INE), and ICF 2018) claims that this trend is on the rise, after having registered a decrease between 2003 and 2011 (p. 69).

Mozambique has worked extensively towards improving primary schools attendance: the gross attendance rate in primary education is $98.8 \%$ for girls and $104.4 \%$ for boys ${ }^{1}$ ((MISAU), Instituto Nacional de Estatística (INE), and International 2013). This, however, decreases to $38.2 \%$ for girls and $42.3 \%$ for boys in lower secondary (grades $8-10$ ), identifying the transition to secondary school as the phase in which major gender disparities become apparent ${ }^{2}$. This difference may be understood in association with the impact of pregnancy, which accounts for $39.1 \%$ of the total dropouts in secondary schools (Eloundou-Enyegue, Stycos, and Jah 2004). It is in response to these concerns that decree $39 / \mathrm{GM} / 2003$ was developed, informed by Millennium Development Goals 2 and 3.

Policy 39/GM/2003 (Nguenha 2003) intervenes in order to retain girls within education and bridge the gender gap by tackling pregnancies within schools. It indicates that pregnant girls should be transferred to night courses together with their partners, if in the same school. If partners are members of the school staff, they should be dismissed from employment and reported to the police. Despite the inclusion of fathers within policy guidelines, men are rarely penalized. This is due to mainly two reasons. First, men or boys involved with girls'

${ }^{1}$ This includes late enrolment, as students attending primary school may be beyond the relevant age group.

${ }^{2}$ Secondary school (ESG) is divided into two levels: the first lasts three years (grades 8 to 10), while the second covers grade 11 and 12. Primary school has an official entry age of six and a duration of seven grades. However, because of late enrolment, temporary dropouts and other delays, entry age for secondary school may not be set at 13 for all pupils. The number of secondary schools throughout the country is more limited than primary schools, meaning that classes may be excessively large and pupils may live very far away from their schools (UNESCO-IBE 2010). 
pregnancies are not necessarily attending the same school as the girls. They are often members of the community, therefore unaffected by the policy. Second, teachers' involvement with schoolgirls is perceived to be high in Mozambique (Arthur and Cabral 2004). However, because of the low supply of teachers combined with a high demand for schooling, teachers are likely to continue to work unaffected by the decree's disposition.

Chilisa (2002) categorized Mozambique as adhering to rigid expulsion policies. The country has since then adopted a continuation policy, enabling pregnant girls to remain in education. Decree 39/GM/2003 marks thus a shift and reflects Mozambique's process of (wider social) transition. However, this policy has been criticized as exclusionary (Parkes et al. 2013), as the very text of the policy produces a deficit view of the pregnant schoolgirl, thereby encouraging dropout (Salvi 2016). Pregnant schoolgirls, as a consequence, actively work so that their pregnancies are not found out about: the aim is to remain in their day classes. Here, I tease out the specific mechanisms through which the policy is implemented: these play a role in shaping identities from an institutional perspective. By doing this, I claim that such identities are imposed upon young people, subsequently pushing out of the educational system those who fail to abide. To this purpose I use the concept of gender regime (Kessler et al. 1985, Dunne 2007) in order to consider how identities are regulated and normalized within institutional contexts and through specific practices.

The paper is organized as follows. The next section expands on Decree 39/GM/2003, the operationalization of which constitutes the main analytical contribution of this paper, and situates my claims within the existing literature and theoretical framework. Section 3 considers the methods used to generate data. Section 4 critically examines school practices aimed at managing in-school pregnancy, while Section 5 considers the identity regimes normalized through specific school practices. I use this last section also to reflect on how identity regimes 
shed some light over the institutions that produce them, and not only over the individuals they wish to categorize.

\section{Institutional Regimes of Identity}

Decree 39/GM/2003 proposes exclusion from one form of schooling while also suggesting a form of inclusion through exclusion (Foucault 1994, 78): pregnant schoolgirls are allowed to remain in education, provided they are transferred to an alternative setting. This practice can be illuminated by what Foucault calls 'modes of objectification' $(1991,12)$. Transfer works as a practice of segregation, or a 'dividing practice', in that pregnant schoolgirls are removed from their classes and positioned elsewhere. Transferring girls to night courses is not just a strategy to deal with in-school pregnancy, but it works as a marker in the attribution of an identity. Night courses were developed for illiterate adults at the end of the Civil War, in an attempt to increase literacy rates, which had plummeted from $20 \%$ in 1983 to $14 \%$ in 1990 (Mungazi and Walker 1997, 84). This way, transfer symbolizes a significant shift in girls' identities: pregnant schoolgirls are no longer children, they are adults. Transfer is thus tightly interwoven with an institutional regime that categorizes individual identities as children or adults, but which struggles to make space for the multiple identities and belongings displayed by young women in education. This consideration weaves in with Switzer (2010), who argues how education may disrupt the child/adult binary by giving Maasai girls in Kenya the chance to be 'students', or 'schoolgirls'. This extends girlhood into a liminal phase that carries the potential of breaking with traditional norms. Yet, this is only possible if such norms are replaced by other sets of norms - Switzer (2010) continues - resulting in the essentialization of this liminal phase. This process inevitably leads to losing the emancipatory potential initially identified, represented by the exclusion of pregnancy from the 'schoolgirl' category. 
The regulations produced in order to manage in-school pregnancy also give visibility to institutional regimes structured around an intersection of gender and age. The concept of institutional regimes was first coined by Kessler et al. (1985) and then articulated by Dunne $(2007,502)$ in relation to gender identities in junior and secondary schools in Ghana and Botswana.
A 'gender regime' is constructed through institutional practices (with inscribed social relations of gender), which symbolically construct and regulate everyday life and normalize unequal power relations.

This theoretical lens is particularly powerful as it channels Foucaldian considerations towards an understanding of how identities may be produced in specific settings in order to permit such setting to function - the school in this case. The concept of gender regime builds on a discursive understanding of the subject and enables us to view in-school pregnancy as an event that both invokes and disrupts the norms upheld by gender regimes. For instance, it renders visible the practice of (hetero)sexuality for women, thereby reaffirming specific gender identities in front of communities and social groups. At the same time, gender interweaves with age in defining what behaviors are appropriate, positioning pregnancy outside of the realms of the possible or desirable in a school context. In this sense, pregnancy is strictly connected to sexuality in invoking different discursive formation.

Current theoretical understandings of African sexualities are largely underdeveloped (Undie and Benaya 2006). Most studies tend to rely upon two main discourses framing sexuality in general and young people in particular: a discourse that inherently essentializes local, pre-colonial sexuality, and a second that aims at containing sexuality within the religious 
framework of Christianity ${ }^{3}$. The first, connected to colonial accounts of indigenous sexuality, carries an openness towards sex, which is not a private matter, and as such, is subject to some forms of regulation, usually entailing a degree of control of older generations over the younger ones. Pregnancy follows the same rules as it is considered an outcome of sex: it is generally well received, although heavily regulated (Coovadia et al. 2009). A teenage pregnancy may thus be encouraged in high fertility societies in order for girls to prove their reproductive capacity and qualify as potentially good wives in view of a marriage (Price and Hawkins 2001, 200). For men in such societies, fatherhood is highly valued as it provides a sense of belonging in patriarchal societies and determines which ancestors will protect the baby (Jewkes, Morrell, and Christofides 2009, 681).

Mozambique also remains influenced by a Christian colonial legacy, which confines sex to wedlock and procreation, limiting its legitimate practice to certain age groups and silencing talk about it in public communication (Delius and Glaser 2002). Schools display a similar approach and heavily disapprove of teenage pregnancy through the application of exclusionary or re-entry policies which 'disable girl mothers, thus perpetuating subtle forms of violence against them' (Chilisa 2002, 22). Similar findings from South Africa (Shefer, Bhana, and Morrell 2013, Bhana et al. 2008, Morrell, Bhana, and Shefer 2012) claim that being pregnant or parenting while at school remains influenced by broader discourses on adolescence and female sexuality. These discourses broadly conceptualize teenage pregnancy negatively and teenage mothers as deviants, thereby contributing to excluding young mothers from education, despite inclusionary policies.

\footnotetext{
${ }^{3}$ Christianity refers to the context of this study. Mozambique was a Portuguese colony for approximately four centuries. It attained independence on the $25^{\text {th }}$ June 1975, after 11 years of war. Independence was however followed by 15 years of civil war, until a cease-fire was eventually signed in Rome in 1992. Roman Catholicism is still one of the main religions practised in the country, contributing to shaping social and cultural expectations.
} 
As introduced above, the theorization of pregnancy in relation to gender regimes also calls for a consideration of transitions to adulthood. For instance Osório \& Cruz e Silva (2008, 291) claim that in Mozambique pregnancy is conceived as a rite of passage: pregnancy determines an individual's position within the extended group, as it modifies teenage mothers' social status by distancing them from their peers while strengthening familial bonds. For example, a young mother may need support and guidance in dealing with a newborn baby, which she would receive from her own mother. This is in line with Mkhwanazi's work in South Africa (2010, 356), where 'a girl's transition to motherhood presented an opportunity for both mother and daughter to demonstrate their adherence to local ideals' by fitting in with a gender regime that revolves around motherhood and seniority. It is in the context of weakened formal female initiation rites that pregnancy acquires a high degree of symbolic power.

Age-appropriateness is thus integral to the concept of gender regime, as sexual practices and pregnancy are associated with adulthood. Yet, Macleod (2011), in her elaboration of teenage pregnancy in South Africa, contends that adolescence is to be understood within the category of 'undecidability', as it both excludes and includes childhood and adulthood. Within this perspective, a pregnancy during teenage years corresponds to a breach and can only be understood in terms of a 'general problem-behavior syndrome that includes illicit drug use and drinking' (Musick 1993, 53), or as a deviance (Lawson 1993, 105).

Pregnancy, thus, sits at the crossroad between the two dimensions of gender and age, symbolizing on one hand the difference between man and woman and on the other, between childhood and adulthood. Moreover, it concurrently invokes traditional norms, which may positively value childbearing, and modern ones, which broadly see it as a limitation to human development. These considerations contribute to categorizing individual identity along a life course dimension, which ultimately essentializes age phases. The developmental nature of the 
concept of adolescence makes sense within a modern framework in which the subject is en route to becoming an accomplished adult. Pregnancy acts therefore as a marker of adulthood and disrupts the necessary infantilization of pupils within school structures and practices. This points to an oppressive institutional context, which has also been reported in Ghana by Dunne \& Ananga (2013), and which presupposes that individual identities are linear and coherent.

\section{The Study}

The findings discussed here stem from a wider study on the construction of in-school mothers in Maputo, Mozambique. Between 2007 and 2011 I spent approximately 10 months in the field carrying out qualitative interviews with 10 Ministry of Education officials, 20 secondary school teachers and 33 young people aged 15-24 (25 girls and 8 men/boys) who were/had been pregnant or had fathered a child whilst in education. Data was also generated through 8 focus groups of 3-6 participants, for a total of 40 young men and women (four gender-specific and four mixed-gender). In line with the abductive research strategy I describe below, research participants were recruited through the chain referral method of respondentdriven sampling (RDS), a technique well suited to reach hard-to-find or hard-to-study populations (Bernard 2006, 192). Using this method, initial key informants were asked to identify other potential research participants. Moving from respondent to respondent, the frame eventually reached theoretical saturation (Glaser and Strauss 1976), meaning that no additional data could be gathered to develop new dimensions of understanding. Ethical clearance was granted by the Institute of Education (UK), and prompted me to pay particular attention to power dynamics, considering that I was in the field as a white, European researcher, and to the possibility that sensitive experiences may come to light, due to the nature of the study.

I initially approached academics of the Universidade Eduardo Mondlane (UEM). These vital contacts gave me access to grey literature on pregnancy, schooling and education, while 
acting as initial gatekeepers by introducing me to relevant officials at the Ministry of Education (MINED). It is through them, and by considering which districts had higher occurrences of inschool pregnancy, that I was introduced to the four schools participating in this study: Central School, located in the center of Maputo, Neighborhood School, on the outskirts, District School and District Religious School, in a rural town two-hours away from Maputo. MINED officials introduced me to Head teachers, who then gave access to teachers and to an initial pool of young people. Accessing research participant thus figured more as a 'chain' (Kiragu and Warrington 2012,9 ) than a one-off event, hinting to the circularities and iterative nature of fieldwork. As this process unfolded, I gained access to a number of gatekeepers and potential interviewees.

The first three schools were established in the 1990s as part of socialist modernization efforts, while the latter was a Roman Catholic school. Pupils attending these schools did not necessarily live in the same neighborhoods. This may be for a number of reasons, for instance moving homes to a different part of town while striving to maintain allocated school places and existing relationships.

My research strategy has been broadly abductive (Blaikie 2007). This entailed a process of constant openness to construction, deconstruction and interpretation between myself, research participants, and the theorizations I position this study within. For example, initial findings from individual interviews provided some prompts to focus groups, while the interactions offered by the latter contributed to framing themes initially raised by interviews. Ethnographic immersion provided an ongoing source of both knowledge and questions, which would then be expanded and clarified through data generation.

The analysis I carry out here draws on the theoretical stance discussed in section 2: By considering school practices implementing decree 39/GM/2003, and individuals' responses to 
them, I argue it is possible to better understand how specific gender regimes are invoked and resisted. Conversely, the adoption of this theoretical framework enables me to develop a critical consideration of the policy, which emphasizes its limitations.

I carried out all data collection in Portuguese ${ }^{4}$. The themes raised, especially during individual interviews, were often sensitive. The presence of a research assistant could have hindered proximity, ultimately adding a barrier of complexity to the research context. Being open about my language limitations was also a way to counterbalance power inequalities, as I welcomed advice and corrections from research participants in order to improve my Portuguese.

While in the field, I embraced different identities: NGO intern, consultant, researcher, student and English teacher. Through all of them I remained a white woman in her late twenties/early thirties; in some ways, a clear outsider. Yet, I believe I became a little bit more of an insider on more than one occasion, finding ways to empathize with research participants and identifying similarities in our life histories. This was particularly the case in 2011 when I was myself pregnant with my son. Although I was in my first term, my bump was already quite visible. This offered a further dimension for sharing, especially, but not only, when I interviewed young women who were pregnant or had a baby. I felt this overlap between my identity and theirs created closeness and sisterhood. This illuminates Mazzei and O'Brien's concept of intersectionality $(2009,363)$, which recognizes that researchers simultaneously overlap and diverge from informants. I have been to Mozambique four times: as a woman, and as pregnant woman. These different identities definitely played a role in how others perceived

\footnotetext{
${ }^{4}$ Portuguese is the national language in Mozambique. This remains to date a problematic feature of Mozambican identity: Ethnologue (Lewis, Simons, and Fennig 2013) lists 43 languages spoken in the country.
} 
me, in the interactions that ensued and, more broadly, in the section of 'truth' I became a part of.

\section{Disciplining In-School Pregnancy in Mozambique}

In this section I consider the educational procedures put in place to regulate in-school pregnancy. I first describe the formal arrangements, which directly implement Decree 39/GM/2003 and include the role played by Physical Education (PE) teachers and in-school pregnancy committees. I then move on to expectations placed upon class representatives in extending the regulatory machine. Last, I consider how these practices ultimately compel pregnant schoolgirls to constantly monitor themselves, de facto internalizing the regulatory gaze. Within each sub-section, I raise the contradictions each position entails, and the resultant and contingent sites of resistance. By unpacking them, I clarify the techniques of regulation and their discursive framing.

\subsection{The Formal Regulation of In-School Pregnancy}

In-school pregnancy is strictly monitored through a system that collects information at the ground level by both staff and pupils, compiles it on a termly basis and forwards it to the relevant Education Directorate, which will then submit it to the Ministry of Education (MINED). The MINED compile a report, which is then used both to assess the occurrence of in-school pregnancy throughout the country and the success of the current policy. In this subsection, I explore how information about in-school pregnancies is produced.

The logistics of school attendance generally imply a rather sedentary and passive bodily behavior of both males and females: in class, they often sit still. The surveillance and control in these cases is about keeping pupils quiet. This entails a modernist schism between the body and the mind, whereby the body is the site of 'irrationality, passion and moral corruption 
[while] the mind functions as the seat of reason and restraint' (Bakare-Yusuf 2004, 1). PE as a compulsory subject in schools, by contrast, offers the teacher opportunities to view and pay attention to physicality. During PE, bodies are exposed to an 'inspecting gaze'(Foucault and Gordon 1980, 155), and constantly assessed against institutional regimes. The modes of policing schools are enacted at the beginning of the school year, when teachers learn to 'keep their eyes open', as Mr Nando (District School) puts it:

We find out because we try to keep our eyes open for signs of pregnancy. At the beginning of the school year we try to get to know the students as much as we can. This way, we realize pretty early on if there appear any changes in their behavior or looks.

Interestingly, PE is only compulsory in day classes, as it is not part of the curriculum for adult education, which corresponds to night classes. This suggests that PE in itself acts as a distinction between childhood and adulthood.

PE teachers are therefore key players in the detection of pregnancies, as pregnant girls reported not being at ease participating in PE classes. Protracted absenteeism can alert suspicion even before a pregnancy becomes visible. Ms Ana, PE teacher at Central School, explains:

It is us PE teachers who find out earlier than others. That is because pregnant girls try to avoid classes with us. Once they know they are pregnant, they do not want to exercise as they fear it is going to be harmful for them, but also because in getting changed and moving around the likelihood of being discovered increases.

Avoiding PE is a strategy pregnant girls use to try and prevent being found out and subsequently transferred to night courses. However, being identified by a PE teacher is just the first step of a complex set of procedures, illustrated here below by Ms Antonia, head-teacher of the Central School: 
If PE teachers start to notice girls skipping classes, they approach me, and we make investigations. If the pregnancy is confirmed, we start making some enquiries about the situation of the specific girl, who does she live with? Who is her guardian or carer? We meet together with them, and explain that the girl has now two options. The first is to cancel her matriculation for the time being, so that she can concentrate on the pregnancy and the baby. Then after birth, once her situation is more settled, she can come back to school. The second is instead to directly transfer to night courses and continue her education there. In both cases, we try to make it as clear as possible to both girls and their guardians, that by no means she will be readmitted to day school, even after the birth of the baby.

The investigations Ms Antonia refers to, usually involve questioning other teachers in order to detect any change in the girl's behavior in other disciplines. Possible signs could include failure to go to the board during classes or to leave the classroom during breaks. These are all modes of individual resistance to transfer to night courses that girls enact in an attempt to remain in their classes. However, they also put pregnant girls at an increased risk of being found out about. This positions resistance as a double-edged sword: on one hand, these strategies may lead successfully to the concealment of a pregnancy, while on the other hand they may be cues, even before a pregnancy starts to become visible.

If pregnancy rates are high, schools may decide to create special committees, which are then in charge of dealing with and managing the procedures relating to in-school pregnancy. District School, for instance, established an in-school pregnancy committee composed only of female teachers, as the school's management thought this best for approaching girls on private matters. In this sense, female teachers' identities were conceived in relation to their nurturant femininity and aptitude for pastoral care and counselling, a trend that has also been noted in Botswana's secondary schools (Humphreys 2005, 256). This suggests that a gender regime is 
at work for what concerns teachers as well as students. Interestingly, girls did not necessarily prefer to approach female teachers ${ }^{5}$, as Lidia, a sixteen year old mother who dropped out of school in connection with her pregnancy, indicates:

Researcher: Why did you talk to Mr Nando and not Ms Liliana?

Lidia: I always had a good relationship with him, and I never felt judged. With Ms Liliana, because she is a woman, and she finished her education and now she is a teacher... Maybe she would have looked down at me.

While female teachers are institutionally positioned as more appropriate for counselling and pastoral care, Lidia indicates that interactions may be more complex and nuanced. Female teachers participating in this study were sometimes those who did not have children. Although quite rare, the choice of remaining childless in a pronatalist context has also been identified in South Africa (Bimha and Chadwick 2016). Personal career and academic goals figure there among the main reasons to forgo childbearing. Likewise, Ms Angela, School Director at Neighborhood School, explained how hard it had been to get to where she was, how she had no time for socializing when she was training and how she felt children were not an option. In her experience, women were to choose whether to invest in family life or in their career. I challenged Ms Angela:

Researcher: So pregnancy is really an obstacle to education?

Ms Angela: Indeed it is. I did not have any kids myself, and I am glad, because I had the time and the space to invest in my education, and to get where I am now.

${ }^{5}$ Although female teachers with a clear mandate to engage with in-school pregnancies would approach potential pregnant girls, findings from this study suggest that girls are more likely to share information about their status to male teachers. This identifies a disconnect between girls' needs and school's offer. 
This suggests that education and equality are viewed as a privilege, which pregnancy undermines and threatens. This disjuncture between education and schooling is in line with WID discourse this paper departs from. Given this, establishing women-only in-school pregnancy committees may be doubly problematic. Not only does it rely on an oppressive gender stereotype, one that imposes specific gender regimes, but also one that constructs these encounters as inherently flawed, as Lidia's decision not to approach a woman suggests.

Ms Liliana, District School teacher and director of the in-school pregnancy committee, claimed:

I am a member of a commission of teachers, whose role is exactly to find out about pregnancies, and to provide girls with guidance and support. My approach is to try and talk to them [girls who are suspected of being pregnant]. I try to find out what their problems are and in what ways I can be of any help. Especially if I start to notice that their grades are going down, and their motivation as well. [...] When we get to this point the conversation is quite intimate, so they usually confess that they are pregnant.

In this first part of our conversation, her tone of voice was very calm, quiet, and almost sweet. I could detect a clear concern for girls' wellbeing, which I thought triggered her participation in this committee. However, as our conversation proceeded, I could note that her tone of voice and choice of vocabulary changed as she started to recount what happened after girls admitted the pregnancy. It became harsh, straight to the point and inflexible:

Researcher: So what do you tell them when they admit they are pregnant?

Ms Liliana: I talk straight and very clearly to them. I ask them who the father is. [...] If they are attending $8^{\text {th }}, 9^{\text {th }}$ or $10^{\text {th }}$ grade, they are to be moved to the night course, as we have that option for those classes. 
Quem è o autor? ${ }^{6}$ Who is the father? Or more literally, who is the author, suggests that the agency behind a pregnancy, is not to be located within the girl who carries it, but within the male with whom she had a sexual encounter. However, as I explained above, there are minimal consequences for the father: it is the girls who withstand the worst of this situation. The role of the committee was effectively to both advise and assist pregnant girls by providing support, and to extend the disciplinary apparatus. The tensions between punitive and pastoral roles of in-school pregnancy committees resonate with research carried out in Zimbabwe, where counselling seemed to be a euphemism for punishment (Leach and Machakanja 2000).

In-school pregnancy committees maintain this sort of duality. On one hand, they aim to provide support and guidance. On the other, their formal function is to detect pregnancies and trigger transfer to night courses as indicated by Decree 39/GM/2003. This duality is evident in the words of Mr Estevão, teacher at the District School:

Now we have this commission who deals with pregnant schoolgirls. They are in charge of talking to girls who are suspected of being pregnant. They are good, because they find ways to make the girls open up to them, and admit that they are pregnant.

Admitting a pregnancy is key. Once a pregnancy has been acknowledged, the onus is on the pregnant girl to initiate her transfer to night courses. This application, where girls request to be transferred to night courses, acts as a process of subjectification: girls produce themselves as subjects no longer deserving recognition within mainstream schooling. Transfer to night courses becomes thus a technique of domination through which pregnant girls are generally made a passive object of the decree $39 / \mathrm{GM} / 2003$. Yet, they are active in complying with

\footnotetext{
${ }^{6}$ This is the original Portuguese saying.
} 
institutional prescriptions and in positioning their own identity as they apply to being transferred to night courses.

\subsection{The Informal Regulation of In-School Pregnancy}

The formal regulation of in-school pregnancy is complemented by an informal system, which extends from teachers to class representatives and to individuals themselves. Ms Ana, PE teacher at Central School, clarifies:

Each class has a student representative that should serve as a contact point between pupils and teachers. Among their tasks, they have to inform teachers if something is going on in the classroom. A pregnancy is obviously included in the list of things they are supposed to tell us. So this is another route for us to get the information.

Student representatives bridge the gap between pupils and the teaching staff. In relation to in-school pregnancy, they become active parts of the mechanism of surveillance. Their role is to minimize the potential opposition between teachers and pupils, although they seem to be (re-)producing existing structures of power. As they are students, they contribute to rendering visible the ways in which power actually extends to different levels of society and is diffuse (Foucault 1977), as opposed to being exercised exclusively by some over others. Humphreys $(2005,194)$, in her ethnography of secondary schools in Botswana, defines prefects as the eyes of the school, invoking a 'Foucauldian notion of regulatory surveillance that becomes so internalized to become self-regulatory'. This resonates with the practices I consider in this section.

At the same time, it would be simplistic to assume that prefects are altogether distinct from their peers. For example, it is not unusual for a prefect to fail to disclose a pregnancy, as Carlos, prefect at the Neighborhood School, pointed out in a mixed gender focus group: 
I am a class rep, and yes, I know that I should report girls to the school director if I know or suspect they may be pregnant. I do not do it though. Why? Well first of all because many of the girls in my class already have babies, so what do I do, do I report all of them so they all get transferred? And second, they are my friends you see; I do not necessarily like to put them in difficult situations. As I said, there are so many young mothers that if I were to report them... I would not be too popular if I started to report people, would I?

The position of prefects, like that of in-school pregnancy committees, is characterized by a certain degree of tension. On one hand, it aims to extend mechanisms of surveillance among students and carries the potential of referring information from cohorts up to the school's management. At the same time, prefects may decide to use what they know of the modes of surveillance to make sure pregnant schoolgirls are not identified. For instance, they may know how teachers act upon suspicion of pregnancy, and alert peers accordingly, ultimately protecting them from being found out and subsequently transferred.

School prefects offer a particularly interesting insight as they are part of the student body, albeit being hierarchically positioned in relations to their classmates. This aspect is key in framing their behavior as a site for resistance as they are co-opted to represent their institution, while, at the same time, potentially part of the same student body Decree 39/GM/2013 wishes to discipline. This case represents thus an attempt of power to reproduce beyond the systems of gender and seniority, as prefects can be either male or female, and generally belong to the same age group as their peers.

A further extension of the mechanism of surveillance has to do with the internalization of this gaze. Herminia, a 25-year-old girl with two children, talks about her experience in school: 
When I was 17 and got pregnant things were quite tough. I felt discriminated against by my classmates, I guess. But the relationship with them got so much better afterwards that I think it was not them discriminating against me, but just me fearing they would! In fact, already when I gave birth, my girlfriends were in the hospital with me. They stood by me, kept me company, and made me feel included. I can't say they left me out.

This quote suggests that surveillance extends from teachers to class representatives and peers to the point of being internalized, a feature that illuminates Foucault's theorization: “[...] each individual thus exercising this surveillance over and against himself” $(1980,155)$. Moreover, it hints to the possibility that peers may be of support, contrarily to mainstream literature which suggests peers may be a source of discrimination.

Peer regulation and internalization of the rules are thus key elements of the institutional regulation, playing a part in the process of subjectification of girls. In other words, the mechanisms of constant surveillance work through the internalization of the gaze. Pregnant schoolgirls may fear discrimination. Subsequently, they will pre-empt that possibility by putting some distance between themselves and their peers, thereby becoming active subjects in their self-exclusion. This may occur for instance through failure to engage in socializing activities at school, such as breaks or pre/post-class gatherings.

Internalization is particularly key given student numbers in Mozambican schools. For instance in 2012 the pupil to teacher ratio (PTR) was 58:1 (Directorate of Planning and Cooperation School Construction and Equipment (DIPLAC) and Ministry of Education (MINED) 2013), which makes it hard for teachers to be aware of every pupil. From this perspective, internalisation is a necessary step in the surveillance apparatus, as these numbers render the formal mechanism for the regulation of pregnancy extremely limited. This also explains why the gaze is not only inspecting, but also regulating and normalising, given that it 
already entails an active dimension, since failing to adhere to the norms has consequences. Internalisation also works to render young people aware of the regulations, thereby equipping them with more resources in resisting them. For example, as pupils are generally aware of the policy indications, they know that they are potentially under constant observation, which translates into a constant self-monitoring of their appearances. Similarly, I suggested earlier that prefects may play on the duality of their role by both reproducing the institutional gaze within cohorts, and alerting other pupils of the risks they run.

\section{Conclusion}

Enquiring into in-school pregnancy has allowed me to explore the connections it raises with discourses of age and life-course, what it means to be a child, what it means to be an adult and how these categories are constructed in opposition to one another. Childhood is constructed as a time for options and possibilities, a time for investments in the making of adult identity. Adulthood is characterized instead by the fixity of a choice that has been made, and which cannot be undone. A pregnant schoolgirl 'has shown her path', some of my respondents claimed, meaning that she has clarified which identity to embrace. By so doing, in-school pregnancy becomes a signifier for adulthood and for womanhood, in that girls are expected to embrace a specific gender script, that of the stay-at-home mother and, possibly, the wife.

The intersection of gender and age in defining identities lead me to rely on the concept of gender regimes (Kessler et al. 1985, Dunne 2007) to frame the construction, regulation and normalization of students' identities. This aspect is key as it suggests that the mere existence of in-school pregnancy rules constructs it as problem while offering the means for its regulation. Interestingly, this perspective can also be "plugged in" (Jackson and Mazzei 2012, s5) with African theorization of gender and seniority (Oyěwùmí 1997, Bakare-Yusuf 2004). 
These tend to go beyond the classroom, and frame African identities and constructs within locally sensitive and relevant theorizations.

In-school pregnancy occurs in the liminal space between childhood and adulthood, an extended rite of passage in which identity is moulded against a mythical adulthood. As such, it invokes a plurality of discourses that extend beyond traditional gender regimes to interweave with Western and modern conceptions of education. Inevitably, this may lead to clashes. For example, traditional norms that value pregnancy and parenthood could lead to a specific gender regime, whereby women and mothers are expected to fulfil their identities within the home. Conversely, modern discourses of personal development emphasize the role played by education, devaluing the role played by pregnancy and parenthood in producing identities. Engaging with participants that value both aspects of their identities - as parents and as learners - has allowed me to explore the intersections between different regulatory frameworks and multiple processes of change. This has identified the limitations entailed by considering identities as mutually exclusive. If in-school pregnancy identifies a site of liminality, then the context where that scene takes place is a context of permanent liminality (Szakolczai 2000), as the ideal poles defining the transition are never fully reached or departed from, but constantly renegotiated.

From this perspective, transfer is not a punishment, nor a way to prevent more pregnancies from happening. Transfer becomes part of a more structured mechanism to shape individuals into adults, for whom night classes were initially developed. This points to schools as institutions built around the infantilization of their subjects, which work accordingly towards their normalization. This is in line with that suggested by Dunne and Ananga $(2013,202)$ in Ghana, where "[...] the structure of age relations requires the embodiment and subordinated performance of a 'child' identity especially in relation to their teachers." 
It is in fact the body which is at both at the periphery of the learning process and at the center of the regulatory gaze. The regulatory gaze operates both vertically and horizontally. Teachers, especially PE teachers, are in a prime position to inspect students' bodies, while this is reproduced at peer level by making use of class representatives. Last, the perfunctory gaze is internalized as individual students put their own selves under scrutiny, trying to anticipate, resist and prevent the consequences of others' gazes. I have interpreted this process as both an objectification and subjectification (Foucault and Gordon 1980) that aims at normalizing specific identities while ostracizing others.

Last, the article offers a critical analysis of the implementation of decree 39/GM/2003, which can be used to draw initial policy recommendations. The identities sketched here - those of female students specifically - point to a number of complexities that intersect gender and age in multiple ways. In other words, young people may have a number of commitments and responsibilities beyond their formal education. They could engage in paid employment, activism, or caring for others, for example. Each of these would entail demands on their time, and on their identities, pointing to the necessity of having policies in place that cater to these complexities. Ways forward in relation to educational policies should offer flexibility to encourage the inclusion of diverse identities in the classroom. This, in turns, could lead to improved sense of belonging and, possibly, engagement. The question, then, would be how to implement curricular flexibility, a point this study identifies as a future avenue for research.

Although this study was carried out before the Sustainable Development Goals (United Nations 2015) came into place, the discussion developed here carries important implications for the current policy agenda. For example, this article bridges the gap between developmentalist perspectives that place huge emphasis and potential on education to the detriment of pregnancy (UNFPA 2013) and more anthropological accounts that sanction the 
value of parenthood (Mikell 1997, Iliffe 2005). Ultimately, it argues that in order for development to become sustainable, it is necessary to give visibility to existing discourses and regimes of truth, which may significantly affect individual behaviours and educational outcomes. 


\section{References}

Arthur, Maria José, and Zaida Cabral. 2004. "Essas Gravidezes que Embaraçam As Escolas. Violação dos Direitos Humanos das Jovens Adolescentes." Outras Vozes 7.

Bakare-Yusuf, Bibi. 2004. "Yoruba's Don't Do gender": A Critical Review of Oyeronke Oyewumi's The Invention of Women: Making an African Sense of Western Gender Discourses, Dakar: CODESRIA.

Bernard, H. Russell. 2006. Research Methods in Anthropology. Qualitative and Quantitative Approaches. fourth ed. New York: Altamira Press.

Bhana, D., L. Clowes, R. Morrell, and T. Shefer. 2008. "Pregnant girls and young parents in South African schools." Agenda 22 (76):78-90.

Bimha, Primrose Z. J., and Rachelle Chadwick. 2016. "Making the childfree choice: Perspectives of women living in South Africa." Journal of Psychology in Africa 26 (5):449456. doi: 10.1080/14330237.2016.1208952.

Blaikie, Norman. 2007. Approaches to Social Enquiry. 2nd ed. Cambridge (UK): Polity Press.

Chilisa, Bagele. 2002. "National Policies on Pregnancy in Education Systems in SubSaharan Africa: the case of Botswana." Gender and Education 14 (1):21-35.

Coovadia, Hoosen, Rachel Jewkes, Peter Barron, David Sanders, and Diane McIntyre. 2009. "The health and health system of South Africa: historical roots of current public health challenges." The Lancet 374:817-834.

Delius, P., and C. Glaser. 2002. "Sexual socialisation in South Africa: A historical perspective." African Studies 61:27-54.

Directorate of Planning and Cooperation School Construction and Equipment (DIPLAC), and Ministry of Education (MINED). 2013. Pupil/Teacher Ration 2012.

Dunne, Mairead. 2007. "Gender, Sexuality and Schooling: Everyday Life in Junior Secondary Schools in Botswana and Ghana." International Journal of Educational Development 27:499-511.

Dunne, Máiréad, and Eric Daniel Ananga. 2013. "Dropping Out: Identity Conflict in and out of School in Ghana." International Journal of Educational Development 33 (2):196-205.

Foucault, Michel. 1977. Discipline and Punish: The birth of the prison. London: Penguin Books.

Foucault, Michel. 1994. Power: Essential Works of Foucault. Vol. 1. London: Penguin Books.

Foucault, Michel, and Colin Gordon. 1980. Power/knowledge : selected interviews and other writings, 1972-1977. Brighton: Harvester P. 
Glaser, B.G, and A.L. Strauss. 1976. The Discovery of Grounded Theory: Strategies for Qualitative Research. New York: Aldine.

Humphreys, Sara. 2005. "Schooling Identity: Gender Relations and Classroom Discourse in Selected Junior Secondary Schools in Botswana." PhD, Department of Education, University of Sussex.

Iliffe, J. 2005. Honour in African History. Cambridge: Cambridge University Press.

Jackson, Alecia Youngblood, and Lisa A. Mazzei. 2012. Thinking with theory in qualitative research : viewing data across multiple perspectives. 1st . ed. Abingdon, Oxon ; New York, NY: Routledge.

Jewkes, Rachel, Robert Morrell, and Nicola Christofides. 2009. "Empowering teenagers to prevent pregnancy: lessons from South Africa." Culture, Health \& Sexuality 11 (7):675688.

Kessler, S., D. J. Ashenden, R. Connell, and G. W. Dowsett. 1985. "Gender Relations in Secondary Schooling " Sociology of Education 58:34-48.

Kiragu, Susan, and Molly Warrington. 2012. "How we used moral imagination to address ethical and methodological complexities while conducting research with girls in school against the odds in Kenya." Qualitative Research:1-17.

Lawson, A. 1993. "Multiple Fractures: The Cultural Construction of Teenage Sexuality and Pregnancy." In The Politics of Pregnancy: Adolescent Sexuality and Public Policy, edited by A. Lawson and D.L. Rhode, 101-125. New Haven (CT) and London: Yale University Press.

Leach, Fiona, and P Machakanja. 2000. "Preliminary Investigation into the Abuse of Girls in Zimbabwean Junior Secondary Schools." Gender and Education 9 (1):69-87.

Lewis, M. Paul, Gary F. Simons, and Charles Fennig, D. 2013. "Mozambique." SIL International, accessed 04/03/2014. https://www.ethnologue.com/country/MZ.

Loforte, A.M. 2007. "Inequidades e Valores em Saúde Reprodutiva: Vulnerabilidade das Mulheres num Contexto de Feminização da SIDA " In Mulher, SIDA e o Acesso a Saúde na Africa Subsahariana, sob a perspectiva das Ciências Sociais edited by M.C. Alvarez Degregori, E. Leandro Reguillo and S. DiGiacomo, 27-35. Barcelona: Medicaus Mundi Catalunya.

Macleod, Catriona. 2011. "Adolescence", Pregnancy and Abortion. Constructing a Threat of Degeneration. Edited by Jane Ussher, Women and Psychology. London and New York: Routledge.

Mazzei, J, and E O'Brien. 2009. "You Got It, So When Do You Flaunt It?: Building Rapport, Intersectionality, and the Strategic Deployment of Gender in the Field." Journal of Contemporary Ethnography 38 (3):358-383.

Mikell, G. 1997. "Introduction." In African Feminism: The Politics of Survival in SubSaharan Africa, edited by G Mikell, 1-50. Philadelphia: University of Pennsylvania Press. 
Ministério da Saúde (MISAU), Instituto Nacional de Estatística (INE), and ICF. 2018. Inquérito de Indicadores de Imunização, Malária e HIV/SIDA em Moçambique (IMASIDA) 2015. Maputo/Moçambique: MISAU/Moçambique, INE, and ICF.

Ministério da Saúde (MISAU), Instituto Nacional de Estatística (INE), and ICF. 2013. Moçambique. Inquérito Demográfico e de Saúde 2011. Calverton, Maryland, USA.

Mkhwanazi, Nolwazi. 2010. "Understanding teenage pregnancy in a post-apartheid South African township." Culture, Health \& Sexuality 12 (4):347-358. doi: 10.1080/13691050903491779.

Morrell, R., D. Bhana, and T. Shefer, eds. 2012. Books and Babies: Pregnancy and Young Parents in Schools. HSRC Press.

Mungazi, D. A., and L. K. Walker. 1997. Educational reform and the transformation of Southern Africa: Greenwood Publishing Group.

Musick, Judith S. 1993. Young, Poor and Pregnant. The Psychology of Teenage Motherhood. New Haven and London: Yale University Press.

Nguenha, Alcido Eduardo. 2003. Despacho 39/GM/2003. edited by Ministerio de Educaçao. Maputo (Mozambique).

Osório, Conceição, and Teresa Cruz e Silva. 2008. Buscando sentidos. Género e sexualidade entre jovens estudantes do ensino secundário, Moçambique. Maputo: CIEDIMA, SARL.

Oyěwùmí, Oyèrónkẹ. 1997. The invention of women : making an African sense of western gender discourses. Minneapolis, Minn. ; London: University of Minnesota Press.

Parkes, Jenny, Jo Heslop, Samwel Oando, Susan Sabaa, Francisco Januario, and Asmara Figue. 2013. "Conceptualising gender and violence in research: Insights from studies in schools and communities in Kenya, Ghana and Mozambique." International Journal of Educational Development 3 (6):546-556.

Price, Neil, and Tristan Hawkins. 2001. "Young People's Sexual and Reproductive Health: Towards a Framework for Action." In Managing Reproductive Life. Cross-Cultural Themes in Fertility and Sexuality, edited by Soraya Tremayne. New York and Oxford: Berghahn Books.

Rabinow, Paul, ed. 1991. The Foucault Reader. An Introduction to Foucalt's Thought. London: Penguin.

Salvi, Francesca. 2016. "In the making: Constructing in-school pregnancy in Mozambique." Gender and Education, 30:4, 494-512, DOI: 10.1080/09540253.2016.1219700

Shefer, T., D. Bhana, and R. Morrell. 2013. "Teenage pregnancy and parenting at school in contemporary South African contexts: deconstructing school narratives and understanding policy implementation." Perspectives in Education 31 (1):1-10.

Switzer, H. 2010. "Disruptive discourses: Kenyan Masai schoolgirls make themselves." Girlhood Studies: An Interdisciplinary Journal 3 (1):137-155. 
Szakolczai, A. 2000. Reflexive Historical Sociology. London: Routledge.

Undie, C., and K. Benaya. 2006. "The State of Knowledge on Sexuality in Sub-Saharan Africa: A Synthesis of the literature." JENDA: A Journal of Culture and African Women Studies 8.

UNESCO-IBE. 2010. World Data on Education. VII Ed. 2010/11. Mozambique. Geneva: UNESCO.

UNFPA. 2013. Motherhood in Childhood. Facing the Challenge of Adolescent Pregnancy. In The State of the World Population. York.

United Nations. 2015. Sustainable Development Goals. edited by United Nations. New 